\title{
WEIGHING THE INTEREST OF THE OBLIGED AND THE PUBLIC INTEREST IN THE POLISH TAX LAW
}

\author{
LEONARD ETEL $L^{1}$, MARIUSZ POPŁAWSKI
}

\begin{abstract}
The contribution deals with the introduction into Polish law the principle of weighing the interest of the obligee and the public interest, which will probably be adopted in the new Tax Ordinance Act in Poland in 2019. The considerations in this paper result in a few observations. First, the rule under discussion will be applied both in reference to the provisions of substantive actions taken by tax authorities on the basis of the regulations included in the Tax Ordinance, but also on the basis of other provisions of tax law applied by these tax authorities. Second, the above-mentioned rule will be applicable at the stage of tax law application. It should also be applied in the context of creating tax law. Third, from the essence of this rule results a directive prescribing the interpretation of doubts including the interest of both parties of the tax legal relation. The interpretation of the provisions of tax law through the prism of the rule of weighing interests should be treated as an element of the process of the systemic interpretation. Fourth, the essence of this rule indicates that it should be also taken into consideration in the context of applying the provisions of tax law.
\end{abstract}

\section{Keywords}

Tax law principles; principle of weighing the interests in tax law; interest of the obliged in tax law; interest of taxpayer

\section{JEL Classification: D63, K34, K40}

1 Professor for Tax Law, Department of Tax Law, Faculty of Law, University of Bialystok, Poland. The Author specializes in tax law. He is the author of over 300 books and articles. He is a Chairman of the General Taxation Law Codification Committee in Poland and vice-chairman of the Information and Organization Centre for the Research on the Public Finances and Tax Law in the Countries of Central and Eastern Europe. Contact email: leonard.etel@wp.pl.

2 Professor of the University of Bialystok, Department of Tax Law, Faculty of Law, University of Bialystok. Poland. The author specializes in tax law. He is Vice-Rector for Development and International Cooperation, member of the General Taxation Law Codification Committee in Poland, member of the scientific council of "Public Governance, Administration, and Finances Law Review in the European Union and Central and Eastern Europe". Contact email: mpoplawski@poczta.onet.pl. 


\section{Introduction}

The objective of this paper is an attempt to present a consequence connected with the introduction into Polish law the principle of weighing the interest of the obligee and the public interest, which will probably be adopted in the new Tax Ordinance Act in Poland. Currently, works are conducted aiming at developing a new act including general tax law, which will replace the biding one (Tax Ordinance Act) valid for almost 20 years. They are carried out by the Komisja Kodyfikacyjna Ogólnego Prawa Podatkowego (eng. Codifying Commission of the Universal Tax Law, hereinafter referred to as the Commission). This entity presented the bill of new tax law to the Minister of Finance on 9 October 2017, which completed the 2-year period of work dedicated to the preparation of the bill (Regulation of 21 October 2014). The interest in these issues results from the particular importance of this rule in tax legislation. Directional assumptions of the new Tax Ordinance Act point out that the introduction of a new act is justified, for example, by an increasingly visible need for creating in the Tax Law such mechanisms that would lead to weighing the public interest and the interest of the taxpayer (Kierunkowe założenia, 2015: 6). It is also raised that the issues referring to the matter as delicate as taxes must be solved with respect to taxpayers' rights, but also, which is often forgotten, with considering the interest of the state, or, simplifying, organizations financed by all taxpayers (Kierunkowe założenia, 2015: 132).

The foundation of this paper will be the principle of weighing the interest of the obliged and public interest, hereinafter referred to as the principle/rule of interest weighing, included in Art. 26 of the new Tax Ordinance Bill prepared by the Commission in the version of 6 October 2017 (Projekt ustawy - Ordynacja podatkowa, 2017). In accordance with this regulation, the tax authorities weigh the justified interest of the obliged and public interest (Projekt ustawy - Ordynacja podatkowa, 2017, Art. 26). Problems connected with the application of the mechanism included in the rule in question will be presented in a wider perspective. For this will be accompanied by an attempt to present the current judicial directive of weighing the taxpayer's interest and public interest.

\section{Weighing Interest of Obliged and Public Interest on the Basis of Currently Binding Provisions of Tax Law}

Currently, the rule of weighing the taxpayer's interest and the public interest operates as a directive on judicial decision-making. For it does not result directly from legal regulations but it was formed mainly in judicial decision-making, and also in the doctrine of tax law (Etel, 2017: 363; Kierunkowe założenia, 2015: 137; 
Orłowski, 2009: 184). This rule is currently treated as a typical proceeding rule, operating beside the following rules: legalism, trust, cooperation in the scope resulting from the provisions of law, prohibition of abusing law, proportionality, settlement of affairs, pragmatism, limited application of analogies, and requisition of applying the lifted provisions to assess the occurrences which took place under their rule (Kierunkowe założenia, 2015: 20).

Judicial practice points at the type of regulations, in which the rule in point should be currently applicable. It is raised that the tax authority is obliged to not only establish if there occur premises of the taxpayer's important interest or the public interest, but it is also obliged to weigh the public interest with the individual interest of the party, since it is obliged to do so by Art. 2 of the Constitution of the Republic of Poland (Constitution of 2 April 1997) in any case where a legal norm subordinating the settlement of the affair to the so-called administrative discretion is applicable (Highest Adiministrative Court in Wrocław: I SA/Wr 1458/2001). Thus, in practice, the rule in point is applied foremost in the context of regulations referring to tax reliefs in paying tax obligations (Tax Ordianance of 29 August 1997, Art. 67 and next).

The rule of weighing interests has been expressed in judicial decisions not only directly but also indirectly. It results in the following questions. First, applying the rule of weighing interests, the tax authority should take into consideration various factors concerning the taxpayer, and also the tax creditor. Thus, it is emphasized that in the case of applying the regulations referring to reliefs in tax obligation payments, the authority may adopt different criteria of choice, for example, take into account social and economic circumstances, previous attitude of the taxpayer towards meeting taxation obligations, circumstances of the origins of tax arrears, etc. (Highest Administrative Court: II FSK 2474/2015).

Secondly, the abuse of the rule under discussion will occur if payment reliefs are recklessly applied towards the taxpayer, for this will infringe the public interest understood, for example, as a need for gathering tax incomes. An argument is raised that the tax authority granting a relief in tax obligation payment must bear in mind that the tax obligation is realized and the taxpayer is not hastily exempted from them (Highest Administrative Court in Katowice: I SA/Ka 577/2000).

Thirdly, examining the important interest of the taxpayer, one should not exclusively consider one circumstance, for example, the taxpayer sickness, but also their situation in a broader context. It is also noted that, despite the fact that cancer is undoubtedly a significant event, which should be included in the decision-making process referring to granting or refusal of granting a relief, it is not an automatic basis for canceling tax arrears (Highest Administrative Court: II FSK 1842/2010). 
Fourthly, verifying the possibility of applying for a relief in tax obligation payment, it is important to keep in mind, due to the criterion of public interest, that the consequences of granting reliefs were not borne by the state only. In this context, an argument is raised that while establishing the public interest it is important to take into consideration the budget situation of the state and it is important to eliminate such situations where the result of the relief will be charging the Treasury with the costs of aid (Voivodeship Administrative Court in Warsaw: III SA/Wa 1410/2009).

\section{Rules of Weighing Interest of Obliged and Public Interest as a Rule Referring to Modus Operandi of Tax Authorities and Settling Tax Affairs}

On the grounds of currently binding provisions the rule of weighing interests, as presented above, is a judicial decision-making rule of a typically proceeding nature. After the introduction of a new tax law, this rule will be able to be counted among the rules of operating tax authorities and settling tax affairs (Kierunkowe założenia, 2015: 20, 136). In addition, it will be a general rule of tax law, and not just a proceeding rule, which is demonstrated in the title of chapter 2: "General rules of tax law" in Part I.

The rules of tax authorities' operations and settling tax affairs in the new Tax Ordinance Act will include the following rules: the rule of trust, impartiality and equal treatment, protection of justified expectations, proportionality, purposefulness and effectiveness, pragmatism, objective truth, settling doubts referring to the facts in favor of the obliged, swiftness and plainness of settling affairs, restricted gathering of documents and information, weighing the interest of the obliged and the public interest, active participation of the party, persuasion, arbitral settling of affairs, written form.

The new Tax Ordinance Act will also include three other catalogues of legal rules: program rules (the rule of legality and the prohibition of abusing law by tax authorities (Popławski, 2014a: 27), rules referring to the status of the obliged forming the framework of relations between the obliged and tax authorities (the rule of informing and supporting, cooperation of the obliged with the tax authorities, settling doubts referring to the substance of the provisions of law in favor of the obliged, presumption of honesty of the obliged), rules referring to tax proceedings (the rule of transparency for the parties exclusively, two-tier instance, permanence of the final decisions (Kierunkowe założenia, 2015: 20, 136)). 


\section{Range of Application of New Rule of Weighing Interest of Obliged and Public Interest on Grounds of Tax Law}

As already emphasized, the rule of weighing interests will be on the basis of the new Tax Ordinance Act a universal rule of tax law. Consequently, it will be more extensively applicable than previously. It will be applied in reference to both the provisions of substantive law and procedural law. This rule may be applied on the grounds of actions taken by tax authorities on the basis of the provisions included in the Tax Ordinance Act. It will be applicable for actions performed by tax authorities also on the basis of other provisions of tax law applied by tax authorities. This means that it will be used while applying by tax authorities provisions of tax laws, executive regulations issued on the basis of tax laws, acts of local law issued on the basis of tax laws, as well as the agreements on avoiding double taxation ratified by the Republic of Poland, and other international agreements concerning tax law issues ratified by the Republic of Poland, as well as provisions of the European Union law referring to tax law issues (Projekt ustawy - Ordynacja podatkowa, 2017: Art. 13/11).

In the context of the types of regulations where the rule of weighing interests will be applicable, at the stage of application of tax law, it is important to note the following questions resulting from the justification of the new Tax Ordinance Act. It is underscored that the rule in point will be applied at the stage of application of tax law, in particular in the case of arbitrary decisions, including those on granting reliefs in payment, restoring and prolonging deadlines, abandoning tax collection by the Minister of Finance, in the issue of securing the execution of a tax obligation, making judicial decisions on the liability of third parties (possibility of refraining from holding liable, if it was blatantly unfair), suspending the proceedings on the request of a party, the application of the pain of immediate execution, establishment of the amount of the disciplinary penalty, etc. (Projekt ustawy - Ordynacja podatkowa: justification of Art. 26). It is also underscored that, in fact, in each case these interests in their mutual relation remain important, due to, suffice it to say, that their weighing is required to apply the rule of proportionality, especially in the context of the third of the classic conditions of proportionality of actions resulting in imposing on the obliged obligations or reducing their rights, i.e. the condition of sensu stricto proportionality, assuming weighing the opposed interests and values (Projekt ustawy - Ordynacja podatkowa: justification of Art. 26). The two remaining conditions of the rule of proportionality refers to adequacy and indispensability. It is also emphasized that there are such cases where, because of the form of the legal regulation, there is no room for weighing interests (e.g. in the case of tax measurement), which means, that in such cases, this rule will not be applied, since in the name of the universal rule, a kind of "modification" of the 
content of the tax state of affairs determined in the tax law (Kierunkowe założenia, 2015: 21).

It is important to underscore that weighing these both aforementioned interests should also be taken into account at creating tax law in the scope of, for example, the institution of tax limitation. Not employing this rule in forming tax law could lead to consequences difficult to accept (Popławski, 2014: 63). It would be impossible to recognize as correct a situation where the public interest only is taken into consideration, since at such an assumption, in the institution of limitation could not be any time framework in which tax authorities could claim taxes from the obliged entities. The reverse situation, where only the private interest would be considered at the stage of lawmaking, would also be unacceptable. In this case, we would deal with the situation in which, for example, the institution of limitation would be based on very short time limits (e.g. a few months), within which the tax authorities could claim tax payments from the obliged entities.

\section{Essence of Rule of Weighing Interest of Obliged and Public Interest Introduced to New Tax Ordinance Act}

In accordance with article 26 of the bill of Tax Ordinance, tax authorities weigh the right interest of the obligee and the public interest. A similar rule is articulated in the Art. 7 of the Code of Administrative Procedure, according to which in the course of proceedings the public administration bodies are on guard of the rule of law ex officio or on request of the parties take any actions necessary for thorough explanation of the factual circumstances as well as for settling the affair, bearing in mind the public interest and the proper interest of citizens. A similar rule in reference to arbitrary decisions is also formed in Art. 18/2 of the bill of General Provisions of Administrative Law (Projekt ustawy - Przepisy ogólne prawa administracyjnego; Prawo, 2008: 9-109), underscoring that if the provisions of law indicate that the public administration body employs administrative discretion in settling a case, it should settle it in accordance with the demand of the individual, bearing in mind the need for weighing the reasons of individual, group and public interests disclosed in the case, and the purpose of the legal regulation, as well as the feasibility of the actual implementation of the entitlement, demanded.

In the context of the essence resulting from the rule of weighing interests, the justification of the new Tax Ordinance Bill asserts that the rule of weighing interests results in a directive prescribing interpretation of doubts including the "interests" of both parties of the tax legal relation (Kierunkowe założenia, 2015: 6). Moreover, it is cogently observed that it is not really a novelty since this way 
of law interpretation results from the Act of 2 April 1997, the Constitution of the Republic of Poland (Kierunkowe założenia, 2015: 6). Consequently, the entities interpreting the provisions of tax law should take into consideration, as one of the elements of interpretation, also the need for including the weighing of both aforesaid interests while establishing the meaning of a particular provision of tax law. The interpretation of the provisions of tax law through the prism of the rule of weighing interest, i.e. at including and weighing the booth aforesaid interests should be treated as an element of the process of systemic interpretation. The prescription of interpreting the regulations in accordance with legal rules is one of the most fundamental directives of the systemic interpretation of the law (Morawski, 2014: 130 and next). The literature points out that within the framework of systemic interpretation the issues connected with, among other things, the role of the rules of law are discussed (Nowacki, Tobor, 2007: 199), and also that within the framework of systemic interpretation operates a directive including the structures of an act of law, where the substance of the directive is drawing interpretative argumentation from the structure of the act of law (Brzeziński, 2008: 104).

The rule under discussion will be more broadly applied. The rule should be taken into account also in the context of applying the provisions of tax law. This means that the action of the tax authority performed on the basis of a provision of tax law should be verified through the prism of this rule if the provision grants the tax authority any room for administrative discretion. For the tax authority, applying a provision of law takes particular actions affecting the rights and responsibilities of the taxpayer. However, it should do it taking into consideration the rule in the scope resulting from this regulation.

Taking into account the considerations presented above on the possibility of applying the rule of weighing interests, one may distinguish three categories of the provisions of tax law. The first group includes the provisions of tax law where the rule of weighing interests affects their interpretation and, consequently, the establishment of their meaning. Such a case takes place, for example, in reference to the provision expressing the principle of proportionality. In accordance with Art. 21/1 of the Tax Ordinance Bill, tax authorities will take only such actions imposing responsibilities on the obliged or limiting their rights, which enable to reach the statutory goal, are necessary for its achieving and bring results commensurate with the responsibilities imposed on the obligee or the limitations of their rights. Establishing the meaning of the notion of "actions bringing results commensurate with the responsibilities imposed on the obliged", the authority should weigh the interest of the obligee (the actions taken by the authority should not create additional responsibilities for the obliged of similar or higher degree of intensity than the obligations resulting from the provisions of tax law) as well as the public interest (the actions taken by the tax 
authority should sufficiently serve to perform the responsibilities resulting from the provisions of tax law).

The rule of weighing interests at the stage of interpretation of the regulations should also be taken into consideration in the case of regulating the swiftness of proceedings. In accordance with Art. 24/1 of the Tax Ordinance Bill, tax authorities act on the case insightfully and swiftly, employing possibly simplest means leading to its settlement. The tax authority, assessing what should be understood as the simplest means of action, should weigh both the interest of the taxpayer (the means should interfere in the current affairs and impede the taxpayers operations as little as possible), but also the public interest (the means should not generate very high costs of its application for the tax authority).

The rule of weighing interests also in the context of the interpretation of the regulation will be also applicable in the case of regulations concerning the general clause against avoiding taxation. In accordance with Art. 35/1 of the Tax Ordinance Bill, the action performed foremost in order to gain a tax advantage, contradictory in the particular circumstances with the subject and aim of the tax law, does not result in achieving a tax advantage, if the modus operandi was artificial (tax avoidance). The tax authority, deciding the meaning of the concept of performing a particular action in the circumstances contradictory to the subject and aim of the tax law, should, on the one hand, take into account the private interest (the aim of the tax law may be stimulating certain behaviors of the taxpayer through exception, exemption or a tax relief), but also the public interest (the subject of the tax law is generating the possibly highest incomes from taxes).

The application of the rule of weighing interests also in the context of the interpretation of the regulation refers to, among other things, the regulation being a basis for issuing the general interpretation of tax law. In accordance with Art. 500/1/1 in connection with Art. 505/1 of the Tax Ordinance Bill, the minister competent for public finances interprets the provisions of tax law, ex officio or on request, bearing in mind decisions of courts and the Constitutional Tribunal or the Court of Justice of the European Union. Similarly, the rule will be applicable in the case of issuing tax explanations. For in accordance with Art. 500/1/2 of the Tax Ordinance Bill, the minister competent for public finances seeks to provide consolidated application of tax law by tax authorities, in particular issuing ex officio general information concerning the content of the provisions tax law and explanation of the provisions of tax law referring to the application of these provisions, including decisions of courts as well as the Constitutional Tribunal or the Court of Justice of the European Union. The rule under discussion should be also applied at the stage of applying the regulations referring to individual interpretations, for in accordance with Art. 513/1 of the Tax Ordinance Bill, the director of the National Treasury Information, 
on request of the concerned, issues, in their individual case, the interpretation of the provisions of tax law (individual interpretation).

The competent authorities, issuing the aforementioned interpretations (general or individual) or tax explanations, should obey the rule of weighing interests. The regulations subject to these interpretations and explanations may include unclear wordings, the explanation of which will require the use of the systemic interpretation, and, what follows, including, among other things, the rule of weighing interests.

The law the regulations where the rule under discussion will concern applying certain regulations of tax law are the other group of provisions of the law The rule in point will be taken into account at the application of the provisions of law also in the scope of, for example, the regulation referring to reliefs in tax obligation payments. In accordance with Art. $217 / 1$ of the Tax Ordinance Bill, the tax authority, on request of the obligee, in the cases justified by an important interest of the obligee or the public interest, may grant reliefs in tax payment (reliefs in payment). In this situation, the authority, having verified the facts, should decide on granting or, alternatively, refusing the relief in the tax obligation payment, taking into consideration the private interest of the obligee (the case should concern an important, special and not regular, need of the taxpayer, which should be protected with the relief in payment), but also the public interest (the case should not really threaten the general possibility of generating incomes from taxes).

The application of this rule should also take place in the context of the application and the selection of the method of securing the execution of tax obligations. The tax authority, being able to apply security on the taxpayer's property, judicial mortgage and tax lien (Projekt ustawy - Ordynacja podatkowa, 2017: Art. 628 and next), should bear in mind the interest of the obligee (the means applied should not limit the possibility of conducting their business), yet also public (the security used should be realistic and refer to the components which could be easily cashed in the event of the taxpayer's refusal to pay the tax voluntarily).

The rule under discussion should also be applicable in reference to the pain of immediate execution. In accordance with Art. 433/1 of the new Tax Ordinance Bill, a non-final decision may be granted the pain of immediate execution, if the tax authority has information that executive proceedings against the party are in progress in the scope of other amounts due, or the party does not have property the value of which corresponds with the tax arrears with the default interest, on which it is possible to establish a judicial mortgage or tax lien, which would enjoy the priority of satisfaction, or the party sells the property of considerable value. Consequently, the tax authority taking a decision on providing the non-final decision with the pain of immediate execution should bear in mind the taxpayer's interest (the execution 
of the decision should not result in the application of such executive means that may threaten the taxpayer's fundamental source of income), but also the public interest (the execution of the non-final decision should prevent taxpayers from avoiding tax burdens through swift and efficient "disposal" of their property, for example, in favor of their families and friends).

The third group of regulations will refer to the regulations, in which the rule of weighing interests will be considered neither in their interpretation nor application. This refers to the provisions of the establishment of the meaning of which does not require the extra-language interpretation. Therefore, the rule of weighing interests cannot be applicable. This refers simultaneously to both regulations which do not require the application of this rule at applying these regulations. Such a situation occurs, for example, in the case of the regulation concerning the right to information and support. In accordance with Art. 42/1 of the Tax Ordinance Bill, the concerned is entitled to receive on demand from the tax authorities information on the rights and responsibilities resulting from the provisions of tax law, as well as support in individual, correct and voluntary performance of the responsibilities and exercise of the rights. It is similar in the case of the regulation concerning the use of the means of electronic communication. For in accordance with Art. 46, the condition of a written form defined in the law is regarded as met if the electronic document including the text is signed with the qualified electronic signature or the electronic signature confirmed by the ePUAP trusted profile or in another way determined in separate regulations. The regulations in reference to which we will not deal with the application of the rule of weighing interests will be also regulations concerning the representation and power of attorney, where, according to Art. 57/1 of the Tax Ordinance Bill, a natural person may take actions in the scope of tax law, if they are fully capable of taking legal actions.

\section{Conclusions}

The considerations in this paper result in the following observations. First, the rule of weighing interests of the obliged and the public interest on the ground of the currently binding provisions of tax law functions as a directive in judicial decisions, and its basis is to be found in Art. 2 of the Constitution of the Republic of Poland (Constitution of 2 April 1997). In should be currently applied in every case where it is possible to apply in the case the legal norm which makes the settling of the case dependent on the so-called administrative discretion. In practice, the subjective rule is applied foremost in the context of the provisions referring to reliefs in tax obligation payment. 
Second, after introducing the new Tax Ordinance Bill, this rule will be possible to count among the rules of operation of tax authorities and settling tax affairs. Moreover, it will be a general rule of the legal law and not only procedure principle. The rule of weighing interests will constitute a particularly important principle among other rules of the general tax law included in the new Tax Ordinance. Its crucial importance has been pointed out in the direction assumptions of the new Tax Ordinance, claiming that it should be articulated in the new Tax Ordinance immediately after the rule of legalism (Kierunkowe założenia, 2015: 19 and next).

Third, in the new Tax Ordinance, the rule under discussion will be applied both in reference to the provisions of substantive actions taken by tax authorities on the basis of the regulations included in the Tax Ordinance, but also on the basis of other provisions of tax law applied by these tax authorities.

Fourth, in the new Tax Ordinance, the rule under discussion will be applicable at the stage of tax law application. It should also be applied in the context of creating tax law.

Fifth, from the essence of this rule included in the new Tax Ordinance, results a directive prescribing the interpretation of doubts including the interest of both parties of the tax legal relation. The interpretation of the provisions of tax law through the prism of the rule of weighing interests should be treated as an element of the process of the systemic interpretation.

Sixth, the essence of this rule indicates that it should be also taken into consideration in the context of applying the provisions of tax law. This means that the action of a tax authority carried out on the basis of the provision of tax law, should be verified through the prism of this rule, if this provision provides the tax authority with any room for administrative discretion.

Seventh, taking into account the possibilities of applying the rule of weighing interests in the light of the new Tax Ordinance, we can distinguish three categories of the provisions of tax law, where the first group encompasses the provisions of tax law, in which the rule of weighing interests will affect their interpretation and, consequently, the establishment of their meaning. The second group of provisions of law is constituted by the regulations where the rule under discussion refers to applying particular regulations of tax law. Finally, the third group of provisions of the law will refer to the regulations in which the rule of weighing interests will be taken into consideration neither in their interpretation nor their application. 


\section{References}

Brzeziński, B.: Podstawy wykładni prawa podatkowego (Fundamentals of interpretation of tax law), Gdańsk: ODDK, 2008.

Etel, L. (ed.): Ordynacja podatkowa. Komentarz (Tax Ordinance Act. Comment), Warszawa: Wolters Kluwer, 2017.

Orłowski, J.: Uzasadnienie decyzji w sprawie ulgi w spłacie zobowiązania podatkowego niebędącej pomocą publiczną (Justification of the decision on tax relief not being a state aid), in: Dowgier, R. (ed.): Ordynacja podatkowa. Wokół nowelizacji (Tax Ordinance Act. Around the amendment), Bialystok: Temida 2, 2009.

Popławski, M.: Nadpłata i zwrot podatku. Zagadnienia wspólne dotyczące realizacji uprawnień podatkowych (Overpayment and tax refund. Common issues related to the implementation of tax entitlements), Warszawa: Wolters Kluwer, 2014.

Popławski, M.: Uprawnienia podatkowe. Procedura dochodzenia należności podatkowych od Skarbu Państwa lub jednostek samorządu terytorialnego (Tax entitlements. Procedure of claiming tax receivables from the State Treasury or local self-government units), Warszawa: Wolters Kluwer, 2014a.

Prawo do dobrej administracji (Right to good administration, the Ombudsman's Newsletter Materials), Biuletyn RPO (Bulleting of the Polish Ombudsman) no. 60 (2008).

Morawski, L.: Zasady wykładni prawa (Principles of law interpretation), Toruń: TNOIK 2010.

Nowacki, J., Tobor, Z.: Wstęp do prawoznawstwa (Introduction to jurisprudence), Warszawa: Wolters Kluwer 2007.

PL: Constitution of the Republic of Poland, 2 April 1997, as amended.

PL: Tax Ordinance Act of 29 August 1997, as amended.

PL: Regulation of 21 October 2014, on creation, organization and functioning of Commission Codifying Commission of the Universal Tax Law.

PL: Code of Administrative Procedure of 14 June 1960, as amended.

PL: Highest Administrative Court: I SA/Wr 1458/2001.

PL: Highest Administrative Court: II FSK 2474/2015.

PL: Highest Administrative Court: I SA/Ka 577/2000.

PL: Highest Administrative Court: II FSK 1842/2010.

PL: Voivodeship Administrative Court: III SA/Wa 1410/2009

Projekt ustawy - Przepisy ogólne prawa administracyjnego z 29 grudnia 2010 r. (Bill of General Provisions of Administrative Law of 29 December 2010). www.orka.sejm.gov.pl. 
Projekt ustawy - Ordynacja podatkowa z dnia 6 października 2017 r. (Bill of New Polish Tax Ordinance Bill of 6 October 2017 and Its justification). www.mf.gov.pl.

Kierunkowe założenia nowej ordynacji podatkowej przygotowane przez Komisję Kodyfikacyjną Ogólnego Prawa Podatkowego (Directional Assumptions of the New Tax Ordinance Act prepared by the Codifying Commission of the Universal Tax Law), 2015. www.legislacja.rcl. gov.pl. 